\title{
Quality of care, quality of life, and attitudes toward disabilities: perspectives from a qualitative focus group study in Porto Alegre, Brazil
}

\author{
Betina S. Mattevi, ${ }^{1}$ Juliana Bredemeier, ${ }^{1}$ Cláudia Fam, ${ }^{1}$ \\ and Marcelo P. Fleck ${ }^{1}$
}

Suggested citation

Mattevi BS, Bredemeier J, Fam C, Fleck MP. Quality of care, quality of life, and attitudes toward disabilities: perspectives from a qualitative focus group study in Porto Alegre, Brazil. Rev Panam Salud Publica. 2012;31(3):188-96.

ABSTRACT Objective. To explore the concepts of quality of life (QOL), quality of care (QOC), and attitudes toward disabilities in Porto Alegre, Brazil, from the perspective of people living with disabilities, including their relatives and caregivers.

Methods. This was a qualitative study that interviewed a total of 23 participants in five focus groups, during May-August 2006. After an open discussion about QOL, the WHOQOL-Bref, a generic questionnaire for the assessment of $Q O L$, was presented to participants. The study was performed simultaneously in 15 international centers. Analysis was based on Bardin's content analysis.

Results. Regarding QOL, important themes that emerged were: work, education, leisure, universal accessibility, integration in the society, and social inclusion. Concerning QOC, professional qualifications, disabilities-related training for health and education professionals, and access to health services were considered important. Regarding attitudes toward disabilities, the participants perceived the attitudes of others, especially of caregivers, to significantly impact the QOL of people with disabilities.

Conclusions. People living with disabilities value many of the same themes considered important by the general public; however, several additional themes specific to disabilities and specific to these groups of participants emerged. This information highlights the importance of taking into account the unique perceptions and cultural traits of the target population when measuring $Q O L, Q O C$, and attitudes toward disabilities.

Key words Disabled persons; quality of life; quality of health care; attitude to health; focus groups; qualitative research; Brazil.

Disability is the generic term adopted by the World Health Organization (WHO) to describe the physical impairments, activity limitations, and partici-

Hospital de Clínicas de Porto Alegre, Programa de Pós-Graduação em Ciências Médicas (Psiquiatria), Universidade Federal do Rio Grande do Sul (UFRGS), Porto Alegre, Brazil. Send correspondence to Betina Mattevi, bmattevi@sms.prefpoa.com.br patory restrictions caused by a health condition (1). Currently, about 600 million people in the world live with a wide range of disabilities; $80 \%$ of these individuals live in low-income countries (2). This number continues to grow due to the increasing prevalence of chronic diseases, malnutrition, HIV/AIDS, substance abuse, accidents, and other causes, e.g., the aging of the population (2). WHO highlights the importance of reliable disability and rehabilitation information so that equal opportunity and quality of life can be offered to this population (2).

In recent years, quality of life (QOL) has been increasingly used to determine the global impact of diseases and medical treatments, from the patient's per- 
spective. Measures of QOL-conceptualized as "an individual's perception of their position in life in the context of the culture and value systems in which they live and in relation to their goals, expectations, standards, and concerns" -are potentially useful for research purposes and for medical practice $(3,4)$. QOL measurements may also reflect the individual's social perspective on the disease, revealing an increased appreciation for how patients feel and how satisfied they are with treatment (4).

Underlying QOL is the understanding that the experiences of two people with the same degree of disability may differ greatly depending upon their social support networks, living conditions, and even, life expectations. Thus, for an instrument to be sensitive to such complex variations, it must take into account the subjective perspective of the individual.

By the same token, WHO underscores the importance of ensuring basic human rights through an adequate quality of care (QOC) - access to medical care, rehabilitation, and support services that aim to increase independence-to all people with disabilities (2). According to the Pan American Health Organization (PAHO), only 2\% of Latin America's 85 million people with disabilities have access to adequate medical care (5).

Another component influencing QOL of persons with disabilities is the attitudes towards them. Attitudes are defined as the cognitive and behavioral processes that involve judgment and favorable/ unfavorable reactions to different aspects of a given reality (6). Attitudes can either facilitate or hinder functionality, and support or undermine QOL. Moreover, a society's attitudes, beliefs, and prejudices can be major barriers for people with disabilities (7). In terms of access to work, education, and health, an understanding of attitudes and barriers is imperative for designing effective interventions (8-10). However, few studies of attitudes toward disabilities are available.

Most of the available literature presents exploratory research with few measures that permit assessing the construct (11-13). Many studies intended to assess the QOL of people with disabilities have used either generic or health-related scales (14-16). Some have used scales specifically developed for people with disabilities, but they are not cross-cultural tools (17). Other scales are cross-cultural, but assess QOL for only a specific disability (18). The same is true for measures of QOC and attitudes (19, 20). The benefit of a cross-cultural and simultaneously developed instrument is its capability to access the construct beyond cultural terms, thereby allowing for cultural comparisons and increasing the external validity of research results.

Responding to this need, WHO developed the project, "Quality of Care and Quality of Life for People with Intellectual and Physical Disabilities: Integrated Living, Social Inclusion, and Service User Participation," known as DISQOL. The DISQOL project seeks to integrate and evaluate the relationships among the concepts of QOL, QOC, attitudes, and disability.

\section{The DISQOL project}

The DISQOL project developed three instruments to evaluate three concepts: quality of life, quality of care, and attitudes toward disabilities. Different versions of the questionnaires were developed: (a) for people with physical disabilities; (b) for people with intellectual disabilities; and (c) for their proxies (relatives and caregivers) (21-24).

The DISQOL project involved three steps:

Step 1-Focus Groups. A qualitative phase when information regarding the three major topics was collected from individuals with disabilities and their relatives and caregivers. The topics elicited served as the basis for the development of the three instruments;

Step 2-Pilot Study. A series of preliminary items were tested among a group of individuals with disabilities in different centers; and

Step 3-Field Test. A final version of the instruments was once again tested.

The first step of the project involved Brazil and 14 other countries (Czech Republic, France, Germany, India, Italy, Japan, Lithuania, Netherlands, Norway, Scotland, Spain, Switzerland, Turkey, and Uruguay). Edinburgh (Scotland) served as the International Coordinating Center.

The present article describes the results of the focus groups carried out with people with disabilities, their relatives and caregivers, and their teachers and health professionals in Porto Alegre, Brazil, in May-August 2006.
The objective of this study was to qualitatively explore the concepts of QOL, QOC, and attitudes towards disabilities and the factors that influence these from the perspective of people with disabilities and their relatives and caregivers.

\section{METHODS}

\section{Design and participants}

This was a qualitative study of five focus groups: Group 1, people with mixed physical disabilities (MPD); Group 2, people with intellectual disabilities (ID); Group 3, people with a specific physical disability, in this case, visual impairment (SPD); Group 4, professionals (P); and, Group 5, relatives and caregivers (RC). The methodology used was internationally standardized by the WHOQOL Group (25). Each group had 4-6 participants from 18-65 years of age.

The sample was conveniently obtained by asking key people in the area of disabilities (professionals in governmental and non-governmental organizations) to indicate potential participants. Individuals who might have different perspectives on the study topics were recruited in an effort to assess different disabilityrelated experiences. Demographic characteristics of participants are shown in Table 1.

\section{Procedures}

After being selected, participants were given written and oral information on the study and were asked to sign a Written Informed Consent (WIC) statement. Sociodemographic data were also collected.

The groups met in a private, quiet location with easy access, and the discussions were recorded and later fully transcribed verbatim. The coordinator (MF) had prior focus-group experience and was assisted by three post-graduate research assistants.

After a brief explanation of the proposed task, participants were invited to discuss questions, such as "What is your understanding of the term QOL?" and "What contributes most to the QOL of people with disabilities?" All contributions from group participants were equally valued, encouraging all to express their personal perspective as freely as possible. Participants with visual dis- 
TABLE 1. Characteristics of the 23 individuals who participated in five focus groups on the perspectives of people living with disabilities in Porto Alegre, Brazil, 2006

\begin{tabular}{|c|c|c|c|c|}
\hline Focus group type & Total (No.) & Female & $\begin{array}{l}\text { Median age in } \\
\text { years (range) }\end{array}$ & Education \\
\hline Mixed physical disabilities & 4 & 2 & $35(20-63)$ & $\begin{array}{l}\text { High school: } 1 \\
\text { College/university: } 3\end{array}$ \\
\hline Intellectual disabilities & 5 & 2 & $19(18-25)$ & $\begin{array}{l}\text { Elementary: } 4 \\
\text { Special education school: } 1\end{array}$ \\
\hline $\begin{array}{l}\text { Specific physical disability } \\
\text { (visual disability) }\end{array}$ & 6 & 1 & $35(21-50)$ & $\begin{array}{l}\text { Elementary: } 1 \\
\text { High school: } 3 \\
\text { College/university: } 1\end{array}$ \\
\hline Professionals & 4 & 4 & $38(28-51)$ & College/university: 4 \\
\hline Relatives and caregivers & 4 & 4 & $54(26-63)$ & $\begin{array}{l}\text { High school: } 1 \\
\text { College/university: } 3\end{array}$ \\
\hline
\end{tabular}

abilities received Braille versions of all the written materials.

So as not to influence their opinions, the WHOQOL-Bref (26), a generic questionnaire for the assessment of QOL, was presented to participants following the open discussion. The relevance of each facet of WHOQOL-Bref was discussed, with participants being given the chance to make suggestions. This was followed by a similar discussion on QOC and attitudes towards disabilities, also prompted by questions, such as "What do you think contributes most to the QOC of adults with disabilities?" and "What is the attitude of people towards others with disabilities?"

\section{Ethical aspects}

The project was approved by the Research Ethics Committee of Hospital de Clínicas de Porto Alegre, Brazil (processes 06-016, 06-020, and 06-021). The WIC statement emphasized the option to withdraw from the study at any moment. Participants with intellectual disabilities were also asked to provide WIC from a parent or guardian. Anonymity and confidentiality were ensured. The research was conducted according to the standards defined by the Declaration of Helsinki (27).

\section{Analysis}

Bardin's content analysis was used as a reference for transcript analysis (28). The Bardin technique employs a set of analytical and systematic procedures that aim to cull indicators from the content, allowing an understanding of the phenomena, while respecting the perspective of interviewees. In the present study, analysis was performed by: (a) independent and exhaustive reading of the transcribed material by three independent evaluators; (b) identification of themes/topics (also called "units of meaning" or "record units"); (c) review and examination of these units to define categories that synthesized the material; (d) reconciliation of the three different versions by means of a panel (the three evaluators and the local project coordinator); and, (e) a comparison of each group's results. The authors took special care to preserve information identifying the origin of each suggestion (i.e., from which group the topic was elicited), given that the connection could enrich the understanding of the mate-

rial. However, all participants' opinions were equally valued, independent of the source group.

A report of the analysis process was sent to the DISQOL Coordinating Center in Edinburgh, Scotland. Analysis and integration of reports from all 15 centers, as well as the development of the pilot measures, were performed by the DISQOL Coordinating Center. A complete explanation regarding the overall process of identifying and developing measures is available elsewhere (21).

\section{RESULTS}

A total of 23 people participated in the five focus groups. On average, each group met for about 3 hours.

\section{Quality of life}

Of the WHOQOL-Bref questionnaire's 24 facets, 20 were mentioned spontaneously by participants. The four facets not spontaneously mentioned were: negative feelings, work capacity, sexual activity, and transportation. Additional items to the WHOQOL-Bref, not previously included, but suggested by the coordinating center, were also spontaneously brought up (Table 2); the same happened with a few completely new ones: meeting basic needs, positive attitudes towards people with disabilities (affection, empathy, value, respect for individual differences, understanding, trust), and access to culture/cultural activities.

TABLE 2. Quality of life facets recommended by DISQOL ${ }^{a}$ that were also spontaneously mentioned by the focus groups in a study of perspectives of people living with disabilities, Porto Alegre, Brazil, 2006

\begin{tabular}{|c|c|c|c|c|c|}
\hline \multirow[b]{2}{*}{ Facet } & \multicolumn{5}{|c|}{ Group $^{b}$} \\
\hline & MPD & ID & SPD & $\mathrm{P}$ & $\mathrm{RC}$ \\
\hline Participation/participation opportunity/integration in the community & $x$ & $\mathrm{X}$ & $\mathrm{X}$ & $x$ & $\mathrm{X}$ \\
\hline Guarantee of civil rights & & & & $\mathrm{X}$ & $\mathrm{X}$ \\
\hline Strength to face adversities/overcome difficulties & $X$ & $X$ & $\mathrm{X}$ & & \\
\hline Autonomy/stimulus to develop & $\mathrm{X}$ & $\mathrm{X}$ & $\mathrm{X}$ & & $\mathrm{X}$ \\
\hline Structured activities & & $X$ & & & \\
\hline Victimization & $\mathrm{X}$ & & & & \\
\hline Discrimination & & & & & $\mathrm{X}$ \\
\hline Respect & & $X$ & $X$ & $X$ & $x$ \\
\hline Acceptance & & $X$ & & $x$ & $X$ \\
\hline Food & $X$ & $X$ & & $x$ & $x$ \\
\hline
\end{tabular}

\footnotetext{
a Acronym for the World Health Organization project, "Quality of Care and Quality of Life for People with Intellectual and Physical Disabilities: Integrated Living, Social Inclusion, and Service User Participation."

b Groups: mixed physical disabilities (MPD); intellectual disabilities (ID); specific physical disability (SPD) (visual); professionals $(\mathrm{P})$; and, relatives and caregivers $(\mathrm{RC})$.
} 
TABLE 3. New quality of life themes spontaneously mentioned by focus group participants exploring the perspectives of people living with disabilities in Porto Alegre, Brazil, 2006

\begin{tabular}{|c|c|c|c|c|c|}
\hline \multirow[b]{2}{*}{ Theme } & \multicolumn{5}{|c|}{ Group $^{a}$} \\
\hline & MPD & ID & SPD & $\mathrm{P}$ & $\mathrm{RC}$ \\
\hline Social relationships & $X$ & & $X$ & $\mathrm{X}$ & $X$ \\
\hline Encouragement & $\mathrm{X}$ & & & & \\
\hline Coping (looking beyond the limitation) & $\mathrm{X}$ & & $X$ & & \\
\hline Positive feelings: motivation & $\mathrm{X}$ & & & & \\
\hline Positive feelings: enjoying life & $\mathrm{X}$ & & & & \\
\hline $\begin{array}{l}\text { Adequate demands (and requirements) to limitations (suit the expectations } \\
\text { of performance to the person's capacity) }\end{array}$ & & & & $\mathrm{X}$ & $X$ \\
\hline Acceptance and disclosure of disability & $X$ & $\mathrm{X}$ & $\mathrm{X}$ & & $\mathrm{X}$ \\
\hline Adapting to the disability & & & $X$ & & \\
\hline Treatment adherence & $X$ & & & & \\
\hline Communication: accessibility/autonomy/privacy/ability & $X$ & & & & \\
\hline Work capacitation (qualifying people to work) & $\mathrm{X}$ & $X$ & $X$ & & $\mathrm{X}$ \\
\hline Job opportunities & & $X$ & $X$ & $\mathrm{X}$ & \\
\hline Work: quotas (hiring quotas for people with disabilities in companies) & & & & $\mathrm{X}$ & $\mathrm{X}$ \\
\hline Work: inclusion & & $X$ & $X$ & $\mathrm{X}$ & $X$ \\
\hline Impact of the limitation & $X$ & $\mathrm{X}$ & & & $X$ \\
\hline Multiplicity of disabilities & $X$ & & & & \\
\hline Access to culture/cultural activities & $\mathrm{X}$ & & & $\mathrm{X}$ & \\
\hline Social opportunities & $X$ & $X$ & $X$ & $\mathrm{X}$ & $\mathrm{X}$ \\
\hline Privacy & $X$ & & $\mathrm{X}$ & & $\mathrm{X}$ \\
\hline Support of the family/caregivers & $\mathrm{X}$ & & $X$ & $X$ & $\mathrm{X}$ \\
\hline $\begin{array}{l}\text { Public policies regarding disabilities (tax credits and controlled cost of } \\
\text { adaptation equipment) }\end{array}$ & & & & & $\mathrm{X}$ \\
\hline $\begin{array}{l}\text { Continuity of projects (of public policies, regardless of the changes of } \\
\text { political parties) }\end{array}$ & & & & $x$ & \\
\hline Social Policy (changes to economic support laws for people with disabilities) & & & & $X$ & \\
\hline Mobilizing to guarantee the rights of disabled people & & & $X$ & & $\mathrm{X}$ \\
\hline Community awareness (and information) & & & $X$ & $\mathrm{X}$ & $X$ \\
\hline Health/Health education & & $X$ & $X$ & $\mathrm{X}$ & \\
\hline Access to quality health (physical and mental) services & & & & $\mathrm{X}$ & $X$ \\
\hline Access to preventive exams & & & $X$ & & \\
\hline Access to medication & & $X$ & & & $X$ \\
\hline Multidisciplinary care & & & & $X$ & \\
\hline Family and caregiver education & & & $\mathrm{X}$ & & $X$ \\
\hline Support to the family & & & & $X$ & $\mathrm{X}$ \\
\hline Meeting of basic needs & & & & $\mathrm{X}$ & \\
\hline Social inclusion (early) & $X$ & $X$ & $X$ & $X$ & $\mathrm{X}$ \\
\hline Education: access, quality & & $X$ & $X$ & $X$ & \\
\hline $\begin{array}{l}\text { Education: preparation (training) of schools to receive people with } \\
\text { disabilities, school inclusion }\end{array}$ & & & $\mathrm{X}$ & $\mathrm{X}$ & $\mathrm{X}$ \\
\hline Special education & & $\mathrm{X}$ & & $\mathrm{X}$ & \\
\hline Sexual education & & & & & $X$ \\
\hline Accessibility & $\mathrm{X}$ & & $X$ & $\mathrm{X}$ & $\mathrm{X}$ \\
\hline Accessibility: high cost & & & $X$ & & \\
\hline $\begin{array}{l}\text { Positive attitudes towards people with disabilities: (affection, empathy, } \\
\text { value, respect for individual differences, understanding, trust) }\end{array}$ & & & $\mathrm{X}$ & $\mathrm{X}$ & $X$ \\
\hline $\begin{array}{l}\text { Negative attitudes towards people with disabilities (underestimation, } \\
\text { prejudice, rejection, abandonment, segregation, indifference, } \\
\text { overprotection, unrealistic expectations) }\end{array}$ & $\mathrm{X}$ & $X$ & $X$ & $\mathrm{X}$ & $X$ \\
\hline Pessimism regarding the prognosis given by the care team and relatives & & & & & $X$ \\
\hline Future expectations & & $X$ & & & $X$ \\
\hline Psychological state & & & & & $X$ \\
\hline $\begin{array}{l}\text { Behavior of the person with disability influencing the attitudes of other } \\
\text { people }\end{array}$ & & $\mathrm{X}$ & & & \\
\hline Being proactive & & & $X$ & & \\
\hline Opportunities/ inequality of opportunities in different areas of the country & & $X$ & $X$ & & \\
\hline Development of capabilities/potential & & & $X$ & & \\
\hline Digital inclusion & & & $X$ & & \\
\hline Opportunities for physical activities (non-competitive sports) & & & $X$ & & \\
\hline Preferential access & & & $X$ & & \\
\hline Access to technology & & & $\mathrm{X}$ & & \\
\hline
\end{tabular}

a Groups: mixed physical disabilities (MPD); intellectual disabilities (ID); specific physical disability (SPD) (visual); professionals $(\mathrm{P})$; and, relatives and caregivers $(\mathrm{RC})$.

\section{Quality of care}

According to the study participants, among topics considered to be very important for better QOC were the professional qualifications of health and education professionals and the caregivers, i.e., that they be specifically trained to treat and care for people with disabilities. A participant recounted a bad experience with an untrained professional, as follows:

“(...) when you find some [care], it's not good, because the professional that should be assisting people is not prepared for the [disabled] person. He opens the office door, looks at the person, gets afraid... The appointment lasts 5 minutes and he prescribes the medication without knowing the cost." (Group 2, professionals)

Also of great importance to QOC were respect, including respect for the sexuality of people with intellectual disabilities, and support for the family and the individual:

“...people cannot understand the deaf; they have no respect for the deaf. And I have no choice; it is not a matter of liking or disliking it. I was born deaf. I like being deaf. I just want to be respected, and have people accept me as I am." (Group 1, mixed physical disabilities)

“...then we have the issue of family support. Families cannot handle the situation without help-it's useless. Often [the disabled person] stays with the mother; the father abandons them. Most of our families are like that. So, the mother is left alone. Because of this child, she does not work... A great symbiosis settles. She has no life, and yet she suffocates that child. I mean, she needs some support so that she can do something else, at least during the time the child is here in the school. .." (Group 2, professionals)

Different aspects of the following topics were mentioned in all focus groups: education, accessibility, protective laws for people with disabilities, and social inclusion (Table 3). The groups also considered the following to be relevant: training health and education professionals to care for people with disabilities, access to the health 
services, and access and continuity of care in the public health system. These topics are closely related to QOC itself, and are what was expected based on previous studies (29-31). Other topics cited by the groups are shown in Table 4.

\section{Attitudes towards disabilities}

All the groups expressed the perception that other peoples' attitudes toward disabilities have an impact on the QOL of people with disabilities. Positive attitudes mentioned in all the groups were: solidarity, empathy, support, and incentives; while the negatives ones were: prejudice, discrimination, and depreciation.

Violence was one of the themes that emerged in the discussion and was perceived by participants to be an attitude toward disabilities:

"Then they abuse, they hit the disabled person. They prohibit everything, say she is crazy, do many wrong things. They are talking badly about the person, how 'you're like this' and 'like that,' as my father says." (Group 4 , intellectual disabilities).

The theme ridicule/depreciation/humiliation, mentioned in all groups, refers to mockery and belittlement suffered by people with disabilities. These disparaging remarks are made by the general public and by family, and even by health professionals:

“. . I went to an ophthalmologist. . . . It was time to leave the room. I had walked around the room so much, I did not know which way to go. I asked him, 'Hey, Doc, should I go right or left?' 'Oh, try groping,' he responded." (Group 5, specific physical disability)

The theme understand the needs of people with disabilities should also be highlighted. The authors could relate it to two attitudes (acceptance versus incomprehension and expectations beyond capa- bilities), which together were mentioned by all groups:

"...the families who see them [the person with disabilities] as they are, and expect from them what they can really give ... are happy people. Both the family and them." (Group 2, professionals)

Interesting and noteworthy was an opinion expressed by participants that people with disabilities are also responsible for changing the culture and attitudes of other people:

“...we, people with disabilities, are sometimes guilty of some things... Posture is very important . . . because we also contribute to the understanding ... to the atmosphere.... When people cross the street helping us or things like that, they do not know [how to help], they have to be guided by us..." (Group 5, specific physical disability)

TABLE 4. Quality of care themes spontaneously mentioned by focus group participants exploring the perspectives of people living with disabilities in Porto Alegre, Brazil, 2006

\begin{tabular}{|c|c|c|c|c|c|c|}
\hline \multirow[b]{2}{*}{ Theme } & \multirow[b]{2}{*}{ Sub-theme } & \multicolumn{5}{|c|}{ Groupa } \\
\hline & & MPD & ID & SPD & $P$ & $\mathrm{RC}$ \\
\hline Accessibility & $\begin{array}{l}\text { Universal accessibility (ramps, grab bars, seats for the obese); audio recording support services for } \\
\text { the visually impaired; public areas suitable for the blind (no holes, rubber floors, protections in public } \\
\text { telephones, wide sidewalks); improved access to the Internet for the visually impaired; adapted } \\
\text { means of transportation; widespread use of sign language; the importance of the existing City Office } \\
\text { of Accessibility and Social Inclusion. }\end{array}$ & $\mathrm{X}$ & $X$ & $x$ & $X$ & $\mathrm{X}$ \\
\hline Education & $\begin{array}{l}\text { Education; special school for mentally disabled; access to education, educational inclusion with } \\
\text { close and continuous monitoring of the process; public schools with resources to assist people with } \\
\text { disabilities; a school for every type of need; more funding for public schools; adapt colleges and } \\
\text { universities to welcome people with disabilities into the classrooms (e.g., material in Braille and sign } \\
\text { language interpreter); schools for the deaf. }\end{array}$ & $x$ & $x$ & $x$ & $x$ & $x$ \\
\hline Legislation & $\begin{array}{l}\text { Laws for job quotas; accessibility laws; social inclusion laws; enforcement of the current laws that } \\
\text { should protect people with disabilities. }\end{array}$ & $\mathrm{X}$ & $x$ & $\mathrm{X}$ & $x$ & $x$ \\
\hline Social inclusion & $\begin{array}{l}\text { Social insertion/inclusion; inclusion with close and continuous monitoring of process; preparation of } \\
\text { regular schools to receive people with disabilities; greater compliance with social inclusion laws. }\end{array}$ & $X$ & $X$ & $x$ & $X$ & $\mathrm{X}$ \\
\hline Professional qualification & $\begin{array}{l}\text { Qualified professionals (doctors, paramedics, nurses, physiotherapists, etc.); professional has } \\
\text { information on diagnosis and disease progress; prepared professionals; effective screening; qualified } \\
\text { healthcare and education professionals to deal with disabled people. }\end{array}$ & & $X$ & $X$ & $X$ & $\mathrm{X}$ \\
\hline Professional training & $\begin{array}{l}\text { Training of health and education professionals to assist people with different disabilities (including } \\
\text { sign language); Training of teachers in regular schools; trained professionals. }\end{array}$ & $\mathrm{X}$ & & $\mathrm{X}$ & $X$ & $\mathrm{X}$ \\
\hline Access to assistance & $\begin{array}{l}\text { Easy access to health care; preferential healthcare service; access to healthcare; equal access for } \\
\text { people with different financial or medical situations. }\end{array}$ & $X$ & $X$ & $\mathrm{X}$ & $X$ & \\
\hline Integrated assistance & $\begin{array}{l}\text { Multidisciplinary care; interdisciplinary care; multidisciplinary assistance in schools; better interaction } \\
\text { between education and health professionals; interdisciplinary teams with a view of the patient as an } \\
\text { individual, not just as a case; transdisciplinary services; integration between the various levels of } \\
\text { healthcare assistance. }\end{array}$ & $x$ & & & $X$ & $\mathrm{X}$ \\
\hline $\begin{array}{l}\text { Preparation for family } \\
\text { and caregivers }\end{array}$ & $\begin{array}{l}\text { Training and information for family and caregivers; involving the family in therapeutic planning; } \\
\text { caregiver training on coping with the needs of people disabled since birth. }\end{array}$ & & & $X$ & $\mathrm{X}$ & $x$ \\
\hline Leisure options & Leisure options; opportunities for integration through leisure activities. & & $X$ & $X$ & & $X$ \\
\hline Access to job & Access to and being valued at work; job opportunities; paid job opportunities. & & $X$ & & $X$ & $X$ \\
\hline
\end{tabular}

a Groups: mixed physical disabilities (MPD); intellectual disabilities (ID); specific physical disability (SPD) (visual); professionals (P); and, relatives and caregivers (RC). 
TABLE 5. Themes of attitudes of others towards disabilities spontaneously brought up by focus groups participants. Focus groups were carried out in Porto Alegre, Brazil; May-August, 2006

\begin{tabular}{|c|c|c|c|c|c|}
\hline \multirow[b]{2}{*}{ Theme } & \multicolumn{5}{|c|}{ Group $^{a}$} \\
\hline & MPD & ID & SPD & $P$ & $\mathrm{RC}$ \\
\hline Stereotyping & $\mathrm{x}$ & $x$ & $x$ & $\mathrm{x}$ & $\mathrm{x}$ \\
\hline Indifference & $\mathrm{x}$ & $\mathrm{x}$ & $\mathrm{x}$ & $\mathrm{x}$ & $\mathrm{x}$ \\
\hline Prejudice & $\mathrm{x}$ & $\mathrm{x}$ & $\mathrm{x}$ & $\mathrm{x}$ & $\mathrm{x}$ \\
\hline Respect/disrespect & $\mathrm{x}$ & $\mathrm{x}$ & $\mathrm{x}$ & $x$ & $x$ \\
\hline Disparagement/depreciation/humiliation & $x$ & $x$ & $x$ & $x$ & $x$ \\
\hline Solidarity & $x$ & $x$ & $x$ & $x$ & $x$ \\
\hline Acceptance/lack of understanding & & $x$ & $x$ & $x$ & $x$ \\
\hline Unrealistic expectations & $\mathrm{x}$ & $\mathrm{x}$ & & $\mathrm{X}$ & $\mathrm{X}$ \\
\hline Underestimation & $\mathrm{x}$ & $x$ & & $x$ & $\mathrm{x}$ \\
\hline Empathy/lack of empathy & $x$ & $x$ & & $x$ & $x$ \\
\hline Pity & $\mathrm{X}$ & & $\mathrm{x}$ & $\mathrm{X}$ & $\mathrm{X}$ \\
\hline Disdain/avoidance & & & $x$ & $x$ & $x$ \\
\hline Discrimination & & $\mathrm{x}$ & & $x$ & $x$ \\
\hline Stigmatization & $\mathrm{X}$ & $\mathrm{x}$ & & & $\mathrm{x}$ \\
\hline Overprotection & & $\mathrm{X}$ & $\mathrm{x}$ & & $x$ \\
\hline Anguish/fear & & & $\mathrm{x}$ & $x$ & $\mathrm{x}$ \\
\hline Rejection and abandonment & & $x$ & & $x$ & $x$ \\
\hline Segregation & $\mathrm{x}$ & $\mathrm{x}$ & & & $x$ \\
\hline Attention & & & & $\mathrm{x}$ & $\mathrm{x}$ \\
\hline Support & $\mathrm{x}$ & $\mathrm{x}$ & & & \\
\hline Benevolence & & & $x$ & $\mathrm{X}$ & \\
\hline Impatience & & $x$ & $\mathrm{X}$ & & \\
\hline Intolerance & $\mathrm{x}$ & $x$ & & & \\
\hline Hope and optimism & $\mathrm{x}$ & & & & $\mathrm{X}$ \\
\hline Pessimism and hopelessness & $x$ & & & & $x$ \\
\hline Shame & & & $x$ & & $\mathrm{x}$ \\
\hline Being take advantage of & & $x$ & & & \\
\hline Cordiality & & $x$ & & & \\
\hline Violence (physical and/or psychological) & & $x$ & & & \\
\hline Distrust & & & & $\mathrm{X}$ & \\
\hline Attention & & & & & $\mathrm{x}$ \\
\hline Curiosity & & & & & $x$ \\
\hline Hypocrisy & & & & & $x$ \\
\hline Negligence & & & & & $x$ \\
\hline Overexposure & & & & & $x$ \\
\hline Affection & & & & & $\mathrm{X}$ \\
\hline Appreciation & & & & $\mathrm{X}$ & \\
\hline
\end{tabular}

Concerning the source of attitude, the caregiver's attitude was considered crucial by people with disabilities to their QOL. Other data elicited by the discussion on attitudes can be seen in Table 5 .

\section{DISCUSSION}

\section{Quality of life}

As observed by a similar study of a specific population in Brazil, partici- pants spontaneously mentioned almost all facets of WHOQOL-Bref (32). This suggests that people with disabilities consider the same aspects important to QOL as do people in the general population. Other studies concur $(33,34)$ that people with or without disabilities value the same factors for QOL.

Results of the present study also revealed some new themes that were not included in the WHOQOL-Bref. Among these, access, training, and inclusion in the workforce were strongly emphasized by all five focus groups, with participants considering these as a means of raising self-esteem and encouraging autonomy among people with disabilities. Similar results were found among a Brazilian population with chronic diseases in which $64.8 \%$ of participants mentioned that the disease interfered with work, study, or domestic activity, limiting these activities or making it necessary to quit (35). A study of adults with epilepsy 
in Brazil observed that the area most harmed by epilepsy was work/gainful employment, and stressed the importance of labor market inclusion for social and economic integration and personal accomplishment (36).

In the present study, a possible reason for the emphasis placed on this aspect may be the incipient encouragement of protective laws newly enacted in Brazil that promote the pursuit of professional careers for the disabled and inclusion in the labor force. Social and economic limitations of the Brazilian population, in general, may also contribute to the value placed on work. As reported by a study of QOL among women with HIV/AIDS, financial concerns appeared as a highly compromised area (37). In the present study, it is likely that access to education and school inclusion were also highlighted for these reasons.

Another aspect mentioned by all five groups was social relations. This finding was similar to that of a qualitative study of people with cystic fibrosis. These patients spontaneously mentioned that the support of the partner, relatives, friends, and work or school mates influenced QOL, pointing towards a relationship between attitudes and QOL in disabilities (38).

Taking into account cultural differences, the following topics that emerged led to local items to be added to the measurement instrument developed for people with disabilities: study opportunities, work opportunities, environmental adaptations to disabilities, and quality and quantity of food (alimentation). These items were included only in the Brazilian version of the questionnaire, to be later tested in a larger sample.

\section{Quality of care}

Universal accessibility (e.g., availability of sign-language interpreters, urban planning with accessibility, traffic signals for the visually disabled, ramps, automated teller machines with voice, adaptations to public transportation, etc.) was considered crucial for both QOL and QOC by all five groups, indicating a possible overlap of these two constructs.

Professional qualification and training of health care and educational professionals were considered the most important aspects regarding QOC. It has been observed that in Brazil there is a perception of comprehensive care as a full range of services, coupled with a continuous and coordinated health care network (39). This view reinforces the importance of using measures to evaluate access to health care (39).

Some of the issues which emerged, such as education, access to employment, and leisure opportunities, are not directly related to the classic concept of QOC. This may have happened because QOC has not been systematically studied in Brazil, and therefore, it is not a known concept among the population of this country. Another possible explanation is related to a study limitation. Given that the focus groups had explored the three topics comprising the DISQOL project (i.e., QOL, QOC, and attitudes towards disabilities), the previous discussion on QOL may have influenced the QOC discussion that followed.

Owing to cultural differences, the topic of access to health care emerged as an item to be added to the Brazilian measurement instrument only.

\section{Attitudes towards disabilities}

Focus group comments included prejudices and other negative attitudes towards people with disabilities, and the importance of respect. This finding reinforces the concept that attitudes of others may have an enormous impact on the lives of people with disabilities (7) and that information and awareness can reduce prejudice $(40,41)$.

Concerning the issue of caring for people with disabilities, the WHO model for functionality and disability is rooted in an understanding that caring is influenced not only by the health professional's knowledge, but also by their attitude toward the patient (1). This was corroborated by the findings of the present study. Additionally, the attitudes of people with disabilities toward themselves and others were thought to influence those of the general public toward disabilities (40), and this relationship was confirmed by the present study as well.

\section{Conclusions}

The material presented shows the unique, and spontaneously-mentioned, perceptions of five groups of people in Porto Alegre, Brazil, who agreed to participate in a discussion on QOL, QOC, and attitudes towards disabilities. These participants valued few items not valued by other groups that met in other DISQOL centers around the world; however there were some additional items. This reinforces both the idea that most items have universal importance (items elicited by most centers), and that there are some idiosyncratic cultural issues (items specific to the center in Brazil). Both should be taken into account when developing measurement scales.

As in any qualitative study, the question of external validity and generalization to other contexts must be examined carefully and goes beyond the purpose of this paper. The results presented here were derived from a small group of people with, or involved with, disabilities, who were intentionally chosen as key respondents. That said, the authors of another study have stated that "the purpose is not to establish a random or representative sample drawn from a population, but rather to identify specific groups of people who either possess characteristics or live in circumstances relevant to the social phenomenon being studied" (42).

This article is not the final word on QOL, QOC, and attitudes towards disabilities, but rather a sound beginning, for there is a lack of studies on the unique perspectives of people with disabilities. These study results can provide a starting point from which to develop actions aimed at reducing stigma toward and improving health and quality of life for people with disabilities. Based on the diverse perspectives identified in this study, a strong recommendation would be that all efforts to form social policies on health and quality of life initiatives for people with disabilities take into account the perceptions of the target population in the context of country and culture.

Acknowledgements. The authors wish to recognize and thank Conselho Nacional de Desenvolvimento Científico e Tecnológico (Brasilia, Brazil) and Fundo de Incentivo à Pesquisa, Hospital de Clínicas de Porto Alegre (Porto Alegre, Brazil) for funding the research project. We would also like to thank the participants of the study and all the people that were engaged in the execution of the project. 


\section{REFERENCES}

1. World Health Organization. International classification of functioning, disability, and health. Geneva: WHO; 2001.

2. World Health Organization. Disability, including prevention, management and rehabilitation. Proceedings of the Fifty-eight World Health Assembly, April 2005. Available from: http://www.who.int/gb/ebwha/pdf_files/ WHA58/A58_17-en.pdf Accessed on 5 April 2011.

3. World Health Organization Quality of Life Assessment Group. WHOQOL: development and general psychometric properties. Soc Sci Med. 1998;46:1569-85.

4. Berlim MT, Fleck MPA. "Quality of life": a brand new concept for research and practice in psychiatry. Rev Bras Psiquiatr. 2003;25(4): 249-52.

5. Pan American Health Organization. TheNewsletter of the Pan American Health Organization. Available from: http://www.paho.org/ English/DD/PIN/ptoday17_aug06.htm Accessed on 5 April 2011.

6. Nolen-Hoeksema S. Fredrickson B, Loftus G, Wagenaar W. Atkinson and Hildegard's introduction to psychology. 15th edition. London: Cengage Learning; 2009.

7. Tervo RC, Azuma S, Palmer G, Redinius P. Medical students' attitudes toward persons with disability: a comparative study. Arch Phys Med Rehabil. 2002;83(11):1537-42.

8. Ville I, Ravaud JF. Work values: a comparison of non-disabled persons with persons with paraplegia. Disabil Rehabil. 1998;20:127-37.

9. Ravaud JF, Madiot B, Ville I. Discrimination towards disabled people seeking employment. Soc Sci Med. 1992;35:951-8.

10. Antonak RF, Livneh $\mathrm{H}$. Measurement of attitudes toward persons with disabilities. Disabil Rehabil. 2000;22:211-24.

11. Amosun SL, Volmink L, Rosin R. Perceived images of disability: the reflections of two undergraduate medical students in a university in South Africa on life in a wheelchair. Disabil Rehabil. 2005;27(16):961-6.

12. McConkey R, Truesdale M. Reactions of nurses and therapists in mainstream health services to contact with people who have learning disabilities. J Adv Nurs. 2000;32(1): 158-63.

13. Aulagnier M, Verger P, Ravaud JF, Souville M, Lussault PY, Garnier JP. Paraponaris A. General practitioners' attitudes toward patients with disabilities: the need for training and support. Disabil Rehabil. 2005;27(22): 1343-52.

14. Arun MP, Bharath S, Pal PK, Singh G. Relationship of depression, disability, and quality of life in Parkinson's disease: a hospitalbased case-control study. Neurol India. 2011; 59(2):185-9.

15. Antonioli CM, Bua G, Frigè $A$, Prandini $K$, Radici S, Scarsi M, et al. An individualized rehabilitation program in patients with systemic sclerosis may improve quality of life and hand mobility. Clin Rheumatol. 2009; 28(2):159-65.

16. Jenkinson C, Fitzpatrick R, Peto V. Healthrelated quality-of-life measurement in patients with Parkinson's disease. Pharmacoeconomics. 1999;15(2):157-65.

17. Cummins R.A. The Comprehensive Quality of Life Scale-Intellectual Disability: An initial report. Aust N Z J Dev Disabil. 1991;17:259-64.

18. Flachenecker P, Vogel U, Simeoni MC, Auquier P, Rieckmann P. MusiQol: international questionnaire investigating quality of life in multiple sclerosis: validation results for the German subpopulation in an international comparison. Nervenarzt. 2011;82(10): $1281-9$.

19. Hiidenhovi H, Laippala P, Nojonen K. Development of a patient-orientated instrument to measure service quality in outpatient departments. J Adv Nurs. 2001;34(5)696-705.

20. Henry D, Keys C, Jopp D, Balcazar F. The Community Living Attitudes Scale, Mental Retardation Form: development and psychometric properties. Ment Retard. 1996;34(3): $149-58$.

21. Power MJ, Green AM, WHOQOL-Dis Group. Development of the WHOQOL disabilities module. Qual Life Res. 2010;19(4):571-84.

22. Lucas-Carrasco R, Eser E, Hao Y, McPherson KM, Green A, Kullmann L, WHOQOL-Dis Group. The Quality of Care and Support (QOCS) for people with disability scale: development and psychometric properties. Res Dev Disabil. 2011;32(3):1212-25.

23. Power MJ, Green AM; WHOQOL-Dis Group. The Attitudes to Disability Scale (ADS): development and psychometric properties. J Intellect Disabil Res. 2010;54(9):860-74.

24. Schmidt S, Power M, Green A, LucasCarrasco R, Eser E, Dragomirecka E, et al. Self and proxy rating of quality of life in adults with intellectual disabilities: results from the DISQOL study. Res Dev Disabil. 2010;31(5): 1015-26.

25. World Health Organization Quality of Life Group. WHOQOL assessment: position paper from the World Health Organization. Soc Sci Med. 1995;41:1403-9.

26. Fleck MPA, Louzada $S$, Xavier $M$, Chachamovich E, Vieira G, Santos L, et al. Application of the Portuguese version of the abbreviated instrument of quality of life WHOQOL-Bref. Rev Saude Publica. 2000; 34(2):178-83.

27. World Medical Association. Declaration of Helsinki: ethical principles for medical research involving human subjects. Available from: http://www.bioetica.ufrgs.br/helsin7. pdf Accessed on 23 Jan 2011.

28. Bardin L. Análise de conteúdo. 4 ed. Lisboa: Edições 70; 2008.
29. O'Donnell O. Access to health care in developing countries: breaking down demand side barriers. Cad Saude Publica. 2007;23(12): 2820-34.

30. Souza EC, Vilar RL, Rocha NSPD, Uchoa AC, Rocha PM. Acesso e acolhimento na atenção básica: uma análise da percepção dos usuários e profissionais de saúde. Cad Saude Publica. 2008;24(Suppl 1):S100-10.

31. Mendoza-Sassi R, Beria JU, Barros AJ. Outpatient health service utilization and associated factors: a population-based study. Rev Saude Publica. 2003;37(3):372-8.

32. Fleck MP, Chachamovich E, Trentini CM. WHOQOL-OLD Project: method and focus group results in Brazil. Rev Saude Publica. 2003;37(6):793-9.

33. Schalock RL. Reconsidering the conceptualization and measurement of quality of life. Em: Schalock RL, Siperstein GN. Quality of life. Volume 1. Conceptualization and measurement. Washington, DC: American Association on Mental Retardation; 1996.

34. Felce D, Perry J. Quality of life: its definition and measurement. Res Dev Disabil. 1995;16: 51-74.

35. Martins LM, França APD, Kimura M. Qualidade de vida de pessoas com doença crônica. Rev Latino-Am Enfermagem. 1996;4(3):5-18.

36. Salgado PCB, Souza EAP. Impacto da epilepsia no trabalho: avaliação da qualidade de vida. Arq Neuro-Psiquiatr. 2002;(60)2B:442-5.

37. Galvão MTG, Cerqueira ATAR, MarcondesMachado J. Avaliação da qualidade de vida de mulheres com HIV/AIDS através do HATQOL. Cad Saude Publica. 2004;(20)2:430-7.

38. Bredemeier J, Gomes WB. Percepção de qualidade de vida de pessoas com fibrose cística: um estudo sobre a adequação dos instrumentos de medida. Rev Psiquiatr Rio Gd Sul. 2007; 29(1):35-43.

39. Conill EM. Avaliação da integralidade: conferindo sentido para os pactos na programacao de metas dos sistemas municipais de saúde. Cad Saude Publica. 2004;20(5):1417-23.

40. Godan A, Brajković L, Fortuna V, Godan L. Attitudes and sterotypes of supporting fields towards the persons with disabilities. Coll Antropol. 2008;32(3):783-91.

41. Dantas FG, Gibran AC, Gustavo AC, Antônio RVRF. Knowledge and attitudes toward epilepsy among primary, secondary and tertiary level teachers. Arq. Neuro-Psiquiatr. 2001; 59(3B):712-6

42. Mays N, Pope C. Rigour and qualitative research. BMJ. 1995;311(6997):109-12.

Manuscript received on 28 January 2011. Revised version accepted for publication on 26 July 2011. 
RESUMEN Objetivo. Explorar los conceptos de calidad de vida, calidad de atención y actitudes hacia la discapacidad en Porto Alegre, Brasil, desde la perspectiva de las personas con discapacidad, incluidos los familiares y cuidadores del individuo discapacitado.

Calidad de atención, calidad de vida y actitudes hacia la discapacidad: perspectivas de un estudio cualitativo con grupos de discusión en Porto Alegre, Brasil Métodos. En este estudio cualitativo se entrevistaron 23 participantes en cinco grupos de discusión entre mayo y agosto del 2006. Después de un debate abierto acerca de la calidad de vida, se presentó el WHOQOL-Bref, un cuestionario genérico empleado para su evaluación. El estudio se realizó simultáneamente en 15 centros internacionales. El análisis se basó en el análisis del contenido de Bardin.

Resultados. Respecto de la calidad de vida, los temas importantes que surgieron fueron el trabajo, la educación, el ocio, la accesibilidad universal, la integración en la sociedad y la inclusión social. Respecto de la calidad de atención, se consideraron importantes la formación profesional, la capacitación relacionada con la discapacidad en los profesionales de la educación y la salud y el acceso a los servicios de salud. Con respecto a las actitudes hacia la discapacidad, los participantes percibieron que las actitudes de los demás, en especial las de los cuidadores, repercuten significativamente en la calidad de vida de las personas con discapacidad.

Conclusiones. Las personas con discapacidad valoran muchos de los temas también considerados importantes por la población en general; sin embargo, surgieron varios otros temas específicos de la discapacidad y de estos grupos de participantes. Esta información destaca la importancia de tener en cuenta las percepciones y los rasgos culturales singulares de la población destinataria cuando se miden la calidad de vida, la calidad de atención y las actitudes hacia la discapacidad.

Palabras clave Personas con discapacidad; calidad de vida; calidad de la atención de salud; actitud frente a la salud; grupos focales; investigación cualitativa; Brasil. 